\title{
Extractive Latifundio and the Low Income of the Extractive Reserve Rio Ouro Preto, Western Amazon
}

\author{
Josimar da Silva Freitas ${ }^{1}$, Alfredo Kingo Oyama Homma ${ }^{2}$, Milton Cordeiro Farias Filho ${ }^{3}$, Armin Mathis ${ }^{4}$, Luciano Felix \\ Florit $^{5}$, Jose Valderi Farias de Souza ${ }^{6}$, Rogerio de Souza Loredo ${ }^{7} \&$ Charles Carminati Lima ${ }^{8}$ \\ ${ }^{1}$ Federal University of Amapa, Macapa, Brazil \\ 2 Embrapa Eastern Amazon, State University of Para, Belem, Brazil \\ ${ }^{3}$ University Center of the State of Para, Belem, Brazil \\ ${ }^{4}$ Federal University of Para, Belem, Brazil \\ ${ }^{5}$ Regional University of Blumenau, Blumenau, Brazil \\ ${ }^{6}$ Federal University of Acre, Cruzeiro do Sul, Brazil \\ ${ }^{7}$ State University of Rio Grande do Sul, Sao Francisco de Paula, Brazil \\ ${ }^{8}$ Federal University of Rondonia, Cacoal, Brazil \\ Correspondence: Josimar da Silva Freitas. Federal University of Amapa, Macapa, Brazil. E-mail: \\ josimarfreitas55@gmail.com
}

Received: July 26, $2021 \quad$ Accepted: September 10, $2021 \quad$ Available online: September 27, 2021

doi:10.11114/ijsss.v9i6.5304 URL: https://doi.org/10.11114/ijsss.v9i6.5304

\begin{abstract}
In an attempt to mitigate the environmental impacts caused by large farmers, extractive reserves (RESEXs) were founded with the objectives of conserving biological diversity and meeting traditional communities' vital needs. This study aimed to evaluate whether the objectives of human needs satisfaction and environmental conservation were achieved based on institutional investments in a RESEX in the Brazilian Amazon. The study was developed through the association method, and we confirmed interference due to the dependence relationship that occurred between the variables of the economic and social groups with the institutional one. Here, we conclude that low investments in social (education and health) and productive policies (roads, transport, and technical assistance) prevent social development and consequently motivate deforestation when families seek to ensure subsistence.
\end{abstract}

Keywords: public policies, human development, environmental conservation

\section{Introduction}

The creation of areas that reconcile nature conservation with the presence of human populations has become a good sustainable model (Barros et al., 2011), since it plays an essential role in protecting natural resources and maintaining ecological balance (Song et al., 2017). The extractive reserve (RESEX) is one of seven sustainable use conservation unit (CU) categories, allowing for permanent traditional communities for the purposes of environmental conservation and social development.

Specifically, for extractivists, the creation of a RESEX implies significant changes in that it guarantees land ownership, provides food security, allows access to financing, encourages production diversification, expands income, and improves inhabitants' living conditions (Cavalcanti et al., 2018).

RESEXs are imposed as a territorial development project that mobilizes actors and rich biodiversity (Teisserenc, 2016), creates an institutional mechanism for resolving land-related conflicts (Allegretti, 2008), and formally institutionalizes territories susceptible to receiving policies from the federal, state, and municipal government (Silva et al., 2013). The "development" to which we refer aims to improve inhabitants' living conditions, and we understand that environmental conservation depends on the treatment of traditional communities.

The challenge is to achieve a balance between the maintenance of natural resources and traditional populations' subsistence (Moura et al., 2009), overcome socio-environmental weaknesses (Brown \& Rosendo, 2000), demand investments in infrastructure (Dias et al., 2016), and take actions that meet the objectives of creation and maintenance (Vitali \& Uhlig, 2010). Therefore, it is essential that managers know how to manage demographic and economic 
changes (Newton et al., 2011), specifically by proposing productive agroextractive strategies that reduce deforestation and burning (Homma, 2016).

Although the objective is to protect the Amazon biome, the existence of these areas against the unbridled exploitation of predatory capital per se does not solve all the problems faced by families living in the RESEXs (Barbosa \& Moret, 2015). When traditional communities lose their traditional livelihood options, they prioritize economic benefits as a subsistence condition (Ribeiro et al., 2020). These new relationships with the forest impact natural and environmental resources, generating significant deforestation annually (Camilotti et al., 2020).

Deforestation affects carbon stocks and climate benefits and is associated with large bovine livestock holdings and the devaluation of the extractive chain (Fearnside et al., 2018; Mascarenhas et al., 2018). The association of productive farming activities and mining caused extractivism to lose economic value (Clement, 2006). Therefore, socioenvironmental policy needs to be pragmatic, with concrete proposals that meet the interests of environmental conservation and improve inhabitants' living conditions (Homma, 2015).

This study advances the understanding of inhabitants' relationship with environmental resources through intervention and evaluation of social and productive public policies and information about local inhabitants' monthly household income. The study aimed to evaluate whether human needs and environmental conservation were achieved based on institutional investments in a Brazilian Amazon RESEX.

Future studies will assess the equilibrium point between conservation and development in order to consider the potential of natural and environmental resources, the organization of cooperatives and associations (from the perspective of improving inhabitants' living conditions), and the state's behavior with a view to socio-environmental promotion.

This article is organized into four sections. First, we describe the material and methods. Second, we present and interpret the results. Third, we discuss the results and highlight the conclusions of the study.

\section{Material and Method}

\subsection{Research Subject}

The RESEX Rio Ouro Preto is located in the municipalities of Guajara Mirim and Nova Mamore, both of which are in the State of Rondonia, $330 \mathrm{~km}$ from Porto Velho. The RESEX (founded on March 13 1990) has an area of 204,631 hectares. It is located between the geographic coordinates $64^{\circ} 18^{\prime}$ and $65^{\circ} 16^{\prime}$ West and $10^{\circ} 35^{\prime}$ and $11^{\circ} 03^{\prime}$ South (Figure 1). This RESEX was created in the same year (1990) as Alto Jurua (AC), Chico Mendes (AC), and Rio Cajari (AP), and is therefore among the oldest in the Amazon.

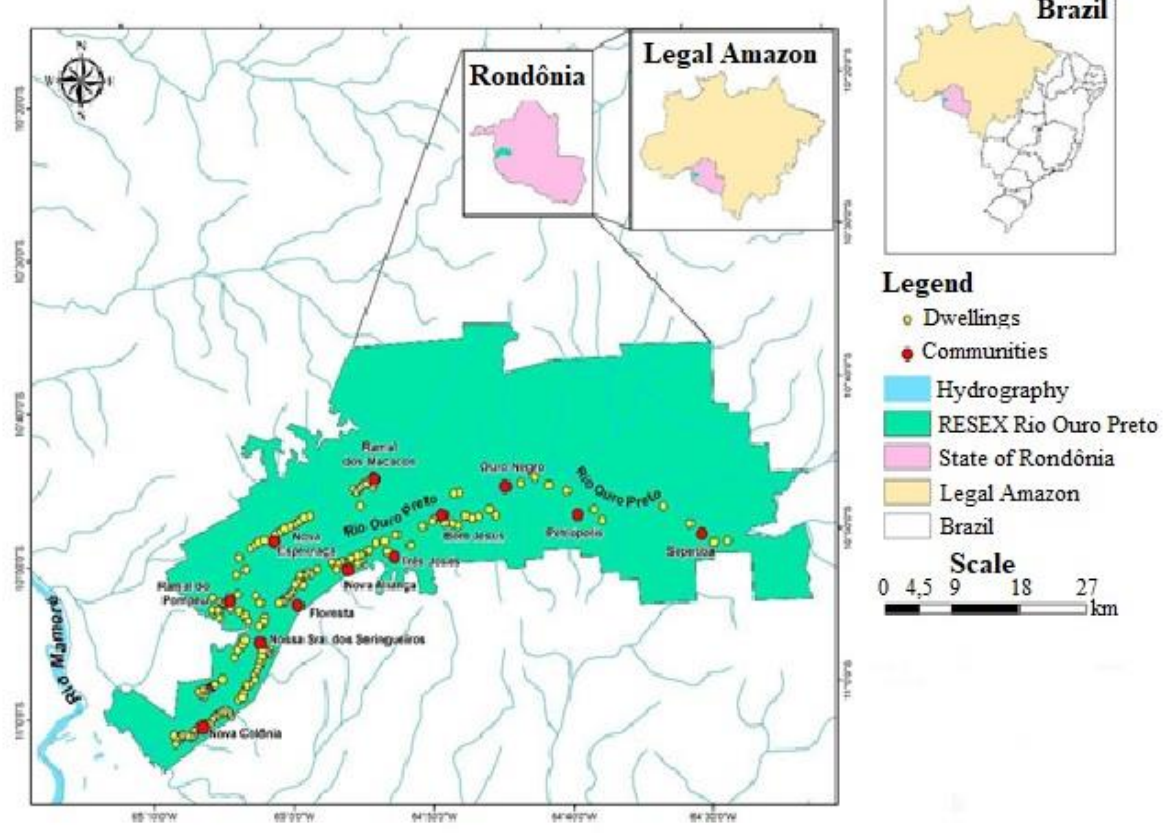

Figure 1. Location of the RESEX Rio Ouro Preto and its spatial elements

Source: The author

According to the last Demographic Census, when the RESEX was created (1990), there were 178 inhabitants (Chico Mendes Institute for Biodiversity Conservation [ICMBio], 2021). About 20 years later, the population expanded to 699 
inhabitants, distributed across 12 communities on the banks of the vicinal roads, rivers, and streams (The Brazilian Institute of Geography and Statistics [IBGE], 2010). However, the population declined due to a lack of schools and incentives for productive activities (Ministerio do Meio Ambiente [MMA], 2014). The RESEX area supports a per capita population density of one inhabitant to 292 hectares or 1,461 hectares per family. At RESEX Rio Ouro Preto most inhabitants own house in the urban area of the city of Guajara-Mirim, and commonly attend RESEX in the period of collection of brazil nuts (Bertholletia excelsa) and carry of productive activities. This phenomenon occurs in other parts of the Amazon.

This scenario characterizes the RESEX as a forest latifundio that is unsupervised because it has been placed under its residents' care. However, with social capital investment and the strengthening of extractive activity, it could become an attractive area to relatives and acquaintances, which would increase the demographic density in the future.

\subsection{Study Delineation}

The study was developed using the association method, and we confirmed interference due to the dependence relationship that occurred between variables (Volpato, 2015). It is important to clarify that the central point of analysis is not in the variables, but in the relationships between them (Volpato, 2013), that is, in the association of interference resulting from the mechanisms, which is the sequence of events that connects the initial affected agent to the final effect (Elster, 1994; Volpato, 2017).

For example, the improvement of the education and health systems depends on expanding networks with investments in physical structure, equipment, and qualified professionals (social group). To expand the productive activities of extractivism and agriculture and livestock, as well as increase the monthly household income (economic group) and reduce deforestation (environmental group), investments in technologies, equipment, and better use of secondary areas (institutional group/state) are needed.

The logic of the dependency relationship is presented as follows: The state interferes in inhabitants' lives in the absence of public policies related to education and health in order to encourage children and young people to migrate to urban centers; however, the lack of state investments in equipment and technologies to stimulate productive activities still results in low incomes and considerable deforestation.

\subsection{Specific Procedures}

Before data collection, it was necessary to submit the project to the Biodiversity Authorization and Information System (SISBIO) of the ICMBio. We entered the field only after approval and authorization from the head of RESEX Rio Ouro Preto.

The survey was applied based on a random sample of 67 parents or guardians within the family establishment, who have lived in the RESEX for at least 10 years. This criterion was necessary due to knowledge of the model, since the study evaluated 30 years of existence based on the variables of the environmental, economic, institutional, and social groups.

In addition, the research instrument was utilized through semi-open questions related to public policies in the areas of education, health, technical assistance, and communication (institutional group); the evaluation of these policies; the inhabitants' perceptions of the improvement of living conditions (social group); credit, agricultural production systems, the extraction economy, livestock, and income (economic group); and the impacts on the environment such as deforestation and burning (environmental group).

The research took place in 11 of the 12 RESEX communities: Bom Jesus, Floresta, Nova Colonia, Nova Alianca, Nossa Senhora do Seringueiro, Nova Esperanca, Ouro Negro, Petrópolis, Ramal dos Macacos, Ramal do Pompeu, and Tres Joses. We did not conduct research in the Sepetiba riverside community because we received information that there were no residents at that moment.

The survey participants were residents who developed combined production such as swidden activities, animal husbandry, and plant and animal extraction (collection of chestnut, acai, and oils; hunting and fishing), and the beneficiaries of income transfer programs. To understand state actions regarding the RESEX, we conducted interviews with environmental analysts from ICMBio.

The survey was administered in the communities in January and February 2017. This timeframe coincided with the water period, requiring the use of a motorized speedboat and a pickup truck that made daily 8-hour journeys by river and land. We approached couples who were responsible for their families. Most of the interviews were conducted in the residences, but approximately $8 \%$ were conducted in two ICMBio de Rondonia offices.

\subsection{Data Analysis}

As a way of comparing the results derived from the recorded survey data, (some extensive) conversations were held with residents and managers. We also resorted to participant observation on occasions when we were welcomed into the residences (ethnographic annotations and recordings of conversations). For the analysis of quantitative data, some 
conversation recordings and observations were added to represent a qualitative effort to understand the reality.

The data derived from the research instruments (surveys) were analyzed by means of descriptive frequency statistics for compatibility with analysis and interpretation, as well as statistical tests of mean, median, fashion, variance, and correlation.

The map was based on spatial data derived from vector and matrix data. The IBGE allowed vector use with local and regional boundaries; the National Water Agency (ANA) allowed drainage cutting on the 1:250,000 scale in the Amazon; the ICMBio, localities, hydrography, and the RESEX management plan and the National Institute of Space Research (INPE/PRODES) provided vector data that were transported to another extension (known as editor) until 1997 and from this period to 2019 .

\section{Results}

RESEX Rio Ouro Preto's share capital is low due to a considerable number of illiterate individuals. In the 12 communities studied, $55.2 \%$ of the interviewees reported being literate, while $44.8 \%$ considered themselves to be illiterate. Tres Joses and Nova Esperanca have a higher concentration of illiterate persons, unlike the New Alliance community, which stands out for its high percentage of literate persons. The other communities were not significant in this regard.

In addition, $52.2 \%$ of the interviewees confirmed the ineffectiveness of social (education and health) and productive (technical assistance and productive incentives) public policies, with $86.4 \%$ saying that the institutions have not offered any collective projects to benefit the local inhabitants. Furthermore, $88.1 \%$ indicated that government institutions do not implement socioeconomic policies that meet the traditional communities' needs.

As an example, Brazil nut collection extractivism takes place annually (December to March) in the RESEX; however, there is crop alternation. This phenomenon occurs due to the cycle between flowering and fruit fall (which takes 15 months), meaning that a high harvest in year X results in a drop in productivity in year Y. Moreover, the Amazon's low precipitation due to its hydrological cycle and the low prices of Brazil nuts affected the monthly household income. According to extractive producers (during the collection period), the monthly income does not amount to half of the minimum wage. Perhaps, with the exception of acai (Euterpe oleracea) that provides net monthly income of 1 to 2 minimum wages during the year, most extractive products have low profitability and reduced participation in monthly income, even when it occurs in abundance, as is the case of babassu palm (Attalea speciosa) (Almeida et al., 2021).

Therefore, producers prefer productive livestock and agriculture activities, specifically for the benefits of milk, meat, and agricultural product diversity. Thus, 36.7\% expressed that they work in agriculture out of necessity, $33.3 \%$ due to knowledge of the crop, and $21.7 \%$ in facilities that commercialize the products. Although they understand the impacts on biodiversity, $42.9 \%$ justify cattle rearing due to the food benefits and because such work meets financial demands in times of extreme need.

For agriculture, the National Credit Program for Strengthening Family Agriculture (Pronaf) benefited 51.5\% of the interviewees through small subsistence projects. The Pronaf Microcredit (Group B) line releases a maximum value of 5,000 reais to individual producers and 15,000 reais to producers with family responsibilities (with an interest rate of $0.5 \%$ per year).

Inhabitants questioned the low values and pointed out that many bureaucracies make financing difficult and that the state does not facilitate rural credit to the RESEX. Figure 2 shows the situation regarding public policies, household income, and the major problems evidenced in the RESEX. 


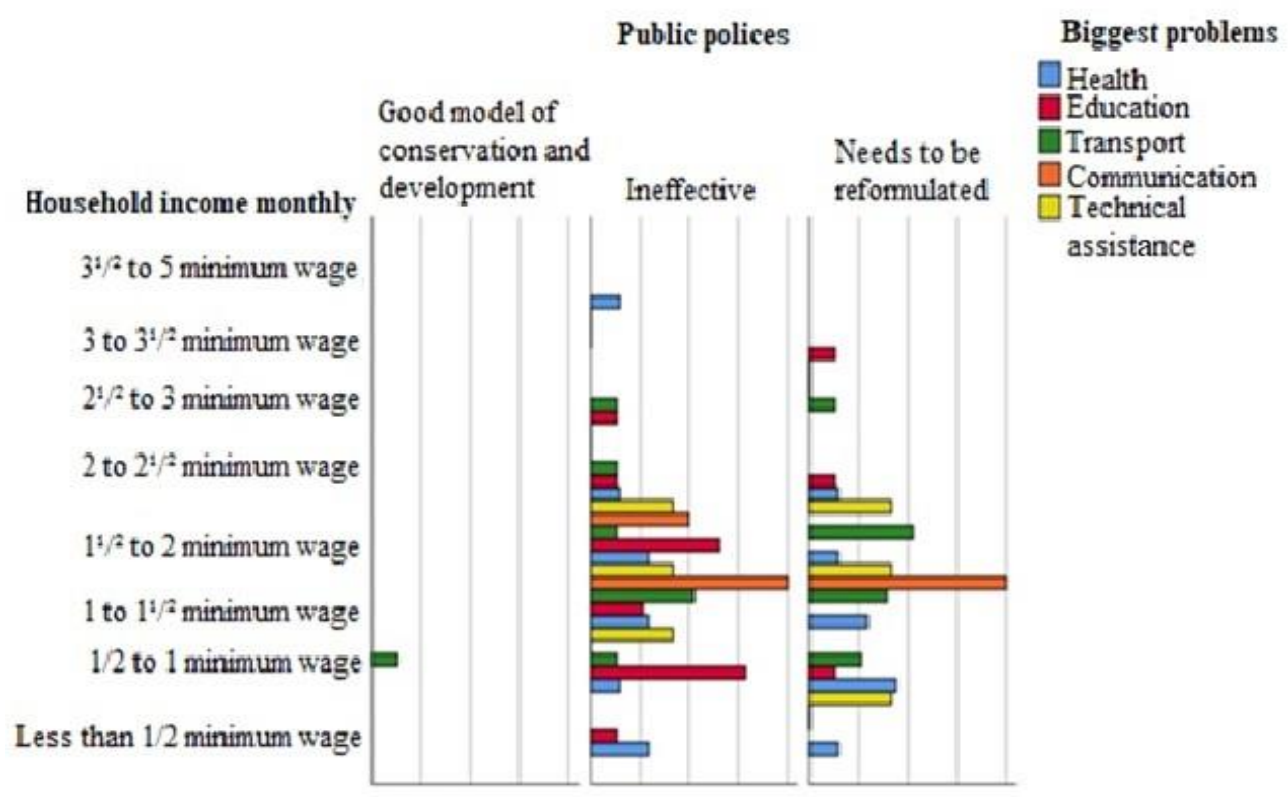

Figure 2. Residents' perceptions of public policies, monthly household income, and the biggest problems faced in

Source: Field research

RESEX Rio Ouro Preto

Based on the interviewees' responses, public policies related to education, health, transportation, communication, and technical assistance are ineffective, and they influence inhabitants' monthly household income. In addition, family responsibilities make it harder to survive, especially backdropped against ineffective policies. This evidence points to the effects on environmental conservation, notably because residents develop and engage in productive activities that have a greater negative impact on environmental resources in an attempt to stave off hunger.

The effects of these decisions result in significant annual deforestation. From this perspective, the data on deforestation are distributed across four stages. The first is 10 years because INPE/PRODES only reports a continuous period. The other periods are distributed between 6 and 7 years (Table 1).

Table 1. Deforestation at RESEX Rio Ouro Preto

\begin{tabular}{|c|c|c|c|c|}
\hline RESEX & Total area & Periods & Deforested hectares & $\%$ \\
\hline \multirow{4}{*}{$\begin{array}{c}\text { Rio Ouro } \\
\text { Preto }\end{array}$} & \multirow{4}{*}{$\begin{array}{l}204,631 \\
\text { hectares }\end{array}$} & Until 1999 & 7,730 & 3.78 \\
\hline & & $2000-2005$ & 8,966 & 4.38 \\
\hline & & $2006-2012$ & 1,957 & 0.96 \\
\hline & & $2013-2020$ & 1,916 & 0.94 \\
\hline \multicolumn{3}{|c|}{ Total } & 20,569 & 10.06 \\
\hline
\end{tabular}

Source: Adapted from INPE/PRODES, 2021

The data indicate that deforestation at the second stage exceeded that of the first stage, even with the shorter length of the first interval (6 years). In contrast, the following two intervals were drastically shorter. The considerable decline in deforestation since 2006 is due to the ICMBio's strict supervision. The values representing deforestation in the last two periods refer to agriculture and cattle rearing combined.

By 2020, 10\% of the RESEX had been deforested, indicating the deforestation of 705 hectares/year since its foundation, that is, almost 1 hectare per capita/year. In addition, RESEX Rio Ouro Preto is undergoing the exclusion (privatization) of approximately 31,489 hectares. Bill no. 2354/2000 and Administrative Process no. 02001.002998/2007-87 stipulate the exclusion procedures.

Negotiation between the ICMBio, rural producers, and the state was established, and the proposal is with the Constitution and Justice Commission (CCJ) of the Brazilian National Congress. The reasons for exclusion are related to the extensive grazed areas that support cattle raising and the need to remove large cattle farmers that contribute to annual deforestation in the RESEX. 


\section{Discussion}

Here, we conclude that low investments in social (education and health) and productive policies (roads, transport, and technical assistance) prevent social development and consequently motivate deforestation when families seek to ensure subsistence. Inhabitants are driven by their vital needs, even if their pursuit of these conflicts with the objectives of the original RESEX model.

Regarding education, there are not enough elementary school vacancies, there is a lack of skilled teachers, and there are high rates of student withdrawal in the CUs: Canutama Forest (79\%), Floresta Tapaua (64\%), RESEX Canutama (63\%), Reserva de Desenvolvimento Sustentavel (RDS) Igapó-Acu (25\%), RDS do Matupiri (53\%), and Parest do Matupiri (74\%) (Costa et al., 2015). This finding is current and pertinent, and we add that children and young people migrate to the urban perimeters due to the lack of schooling opportunities in most communities. Usually, mothers migrate with their children, or children move in with relatives, while fathers remain in the field, working to pay the family expenses. This conclusion confirms the existence of extractive latifundio in the RESEX.

Parents make the sacrifice because they understand that education is one of the most important forms of political and social engagement through voting, chairing local committees, and building mutual trust between people (Helliwell \& Putnam, 2007). Since most parents have literacy issues, they want their children to be highly-educated professionals to avoid similar challenges and crises related to subsistence.

From the perspective of productive activities, the extractivism market depends on government incentive policies to stimulate supply, make the activity attractive, and provide added value (Jaramillo-Giraldo et al., 2017). Furthermore, poorly calibrated emphasis and belief in the inexhaustibility of the extractive economy caused a "regional delay," prompting extractivists to switch to other activities that have a greater environmental impact (Homma, 2011; Peres, 2011). In the RESEX, extractivism faces difficulties related to the inelasticity of supply and the elasticity of demand due to scarcity and commercialization.

Extractive products that have high demand elasticity are more prone to domestication. Rubber producers are discouraged from collecting by the steady decline in prices and the time that must be spent on production. However, chestnut production occurs for the first 3 to 4 months of the year, and prices depend on chestnut stocks, which vary each year. Despite the high prices, the extractive supply has already reached its limit in terms of increasing production.

To improve the situation and stimulate monetary flow, it is necessary to combine non-timber products with swidden and livestock activities (Klimas et al., 2012) in order to provide actors who do not want to rely solely on the extractive economy with opportunities for "local development" (Walter et al., 2016). Agriculture and cattle rearing have become productive activities with more economic potential than rubber and Brazil nut extractivism (Calle et al., 2014; Lopes et al., 2019). Field research supports these conclusions with regard to the influence of external markets in close proximity to the RESEX and facilities for marketing the products.

Among the productive activities, those related to cattle are driven by the local, regional, national, and global markets. Moreover, they have marketing facilities, and they offer producers security guarantees (Gomes et al., 2012). This result in the RESEX is current and relevant, but it threatens the stability of biodiversity and forest conservation. The state should promote food security, provide access to financing, and encourage production diversification in order to expand income and improve inhabitants' lives (Cavalcanti et al., 2018; Lavoie \& Brannstrom, 2019).

The central problem lies in contradictory interests; that is, the state centralizes investments in conservation and leaves traditional communities dependent on dubious social projects, which results in illegal logging, burning, and agricultural expansion (Collins \& Mitchard, 2017). We observed the paradox between conservation and development: It is not possible to maintain the forest and conserve its resources while disregarding traditional communities.

The state does not allow the participation of local actors; strategies are defined, planned, and implemented in a topdown method, with low institutional transparency (Herrera \& Torrent, 2015; Hope, 2016; Moraes et al., 2015). This management model does not meet the interests of Amazonian society due to the lack of both pragmatism in proposal preparation and a greater commitment from public managers (Homma, 2015). We verified that institutional measures make trust and socioenvironmental success impossible, as long as public policies prioritize the environment over people.

The state's management model makes it impossible to maintain biodiversity and for the inhabitants to subsist (Bockstael et al., 2016; Pelegrina-Lopeza et al., 2017). Furthermore, it encourages the expansion of agriculture and livestock (Maciel et al., 2010; Santana \& Pedroso, 2019) and favors increased deforestation (Garrett et al., 2017; Kröger, 2019). This evidence demonstrates that the state has done little to reduce social inequalities, remedy low incomes, and promote conservation.

This context motivates anthropogenic pressures, with deforestation affecting $80 \%$ of tropical forests' ecosystems (Bonilla-Bedoya et al., 2018; Hogg et al., 2016, p. 11; Lui \& Coomes, 2016). The respective negative externalities are specifically low financing, ineffective management, agricultural growth, and illegal activities (Garrett et al., 2017, p. 18; Weisse \& Naughton-Trevesweisse, 2016). 
Deforestation in the Amazon causes regional and global change (Nogueira et al., 2018), intensifies the greenhouse effect, and depletes Earth's biodiversity reserves (Cardoso, 2018). The state does not recognize the inhabitants' economic vulnerability and does not try to create economic opportunities to reduce deforestation in the RESEX (Carmeta et al., 2016; Chena et al., 2017; Haddad et al., 2019; Lagesse \& Thondhlana, 2016).

The quest for family survival has caused changes in the inhabitants' economic rationality. Rules and guidelines lose credibility in the face of a lack of food security and little to no improvement of families' living conditions. Thirty-one years after the first RESEXs were founded in the Amazon, public policies continue to allocate financial resources to conservation, as if there are no human lives plagued by extreme poverty.

Confirming the over-prioritization of conservation and preservation, the federal government recently created Decree no. 10623 (February 9 2021) and instituted the Adopt a Park program, with the objective of promoting the conservation of natural and environmental resources and recovering degraded areas of the federal CU through individuals, and legal (private) national and foreign entities. The value of 50 reais per hectare was established for Brazilians, and 10 euros per hectare for foreigners, for a period of 5 years, with the possibility of renewal. RESEX Rio Outro Preto could receive more than 10 million reais per year, if it finds a national or foreign donor.

In conclusion, the RESEX needs to be consolidated, so that social and productive policies contribute to the economic viability of agroextractivism, even if complemented by sober, non-expansionist agriculture that adapts to the ecosystem and socioeconomic conditions. The state must better recognize the virtues and potentialities of the inhabitants' way of life, so that the surrounding society understands the general benefit of the existence of traditional communities in the RESEX.

\section{Acknowledgements}

We extend our thanks to the ICMBio for providing information and logistical support. We are especially grateful to the managers Albino Gomes and Simone Santos.

\section{References}

Allegretti, M. (2008). A construcao social de politicas públicas. Chico Mendes e o movimento dos seringueiros. Desenvolvimento e Meio Ambiente, 18, 39-59. https://doi.org/10.5380/dma.v18i0.13423

Almeida, H. P., Homma, A. K. O., Menezes, A. J. E. A., Filgueiras, G. C., \& Farias Neto, J. T. (2021). Producao e autoconsumo de acai pelos ribeirinhos do Municipio de Igarape-Miri, Para. Research, Society and Development, 10(9), 1-15. https://doi.org/10.33448/rsd-v10i9.18376

Barbosa, M. A. M., \& Moret, A. S. (2015). Producao e comercializacao da castanha-do-brasil: economia e disponibilidade financeira (subsistencia das familias residentes em reservas extrativistas). Revista de Gestao Sustentavel Ambiental, 4(2), 413-428. https://doi.org/10.19177/rgsa.v4e22015413-428

Barros, F., Pereira, H., \& Vicente, L. (2011). Use and knowledge of the razor-billed curassow pauxi vuberosa (Spix, 1825) (Galliformes, Cracidae) by a riverine community of the Oriental Amazonia, Brazil. Journal of Ethnobiology and Ethnomedicine, 7(1), 2-11. https://doi.org/10.1186/1746-4269-7-1

Bockstael, E., Bahia, N., Seixas, C., \& Berkes, F. (2016). Participation in protected area management planning in coastal Brazil. Environmental Science \& Policy, 60, 1-10. https://doi.org/10.1016/j.envsci.2016.02.014

Bonilla-Bedoya, S., Estrella-Bastidas, A., Molina, J., \& Herrera, M. (2018). Socioecological system and potential deforestation in Western Amazon Forest Landscapes. Science of the Total Environment, 644, 1044-1055. https://doi.org/10.1016/j.scitotenv.2018.07.028

Brown, K., \& Rosendo, S. (2000). The institutional architecture of Extractive Reserves in Rondonia, Brazil. The Geographical Journal, 166(1), 35-48. https://doi.org/10.1111/j.1475-4959.2000.tb00005.x

Calle, D., Vieira, G., \& Noda, H. (2014). Praticas de uso e manejo tradicional de carapa spp. (andiroba) na Reserva Extrativista do Rio Jutai, Amazonas, Brasil. Boletim do Museu Paraense Emilio Goeldi, 9(2), 1-12. https://doi.org/10.1590/1981-81222014000200014

Camilotti, V. L., Pinho, P., Brondizio, E. S., \& Escada, M. I. S. (2020). The importance of forest extractive resources for income generation and subsistence among Caboclos and colonists in the Brazilian Amazon. Human Ecology, 48(1), 17-31. https://doi.org/10.1007/s10745-020-00127-7

Cardoso, C. A. S. (2018). Extractive reserves in Brazilian Amazonia: local resource management and the global political economy (1st ed.). London: Routledge. 274. https://doi.org/10.4324/9781315185156

Carmeta, R., Blackburn, G., Davies, G., Sassi, C., Lima, A., Parry, L., Tych, W., \& Barlow, J. (2016). Does the establishment of sustainable use reserves affect fire management in the humid tropics? Plos One, 11(2), 1-19. https://doi.org/10.1371/journal.pone.0149292 
Cavalcanti, F. S., Batista, G. E. A., \& Souza, E. F. (2018). As unidades de conservacao e a questao do desmatamento no Acre: o papel da RESEX Chico Mendes. $56^{a}$ Congresso Brasileiro de Administracao, Economia e Sociologia Rural (Sober), 29 jul. a $1^{\circ}$ de ago. Campinas: Unicamp.

Chena, X., Lupi, F., \& Liu, J. (2017). Accounting for ecosystem services in compensating for the costs of effective

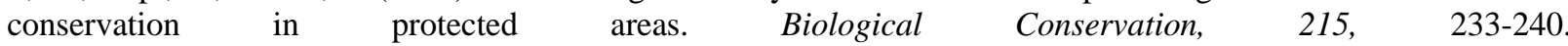
https://doi.org/10.1016/j.biocon.2017.09.013

Clement, C. (2006) A lógica do mercado e o futuro da producao extrativista. In: Kubo, R., Bassi, J., Souza, G., Alencar, N., Medeiros, P. M. \& Albuquerque, P. (Orgs.). Atualidades em Etnobiologia e Etnoecologia. Recife: Nupeea/SBEE, 135-150.

Collins, M., \& Mitchard, E. (2017). A small subset of protected areas are a highly significant source of carbon emissions. Scientific Reports, 7(41902), 1-11. https://doi.org/10.1038/srep41902

Costa, F., Nogueira, A. C., Fraxe, T., \& Witkoski, A. (2015). Recursos comuns e conflitos em unidades de conservacao do Amazonas. In Pereira, H., Fraxe, T., Costa, F. \& Witkoski, A. (Org.). Unidades de Conservacao do Amazonas no interflúvio Purus-Madeira: diversidade cultural e gestao social dos bens comuns. Manaus: EDUA, 187-205.

Dias, T., C., Alan. \& Silva, J. (2016). Return on investment of the ecological infrastructure in a new forest frontier in brazilian Amazonia. Biological Conservation, 194, 184-193. https://doi.org/10.1016/j.biocon.2015.12.016

Elster, J. (1994). Pecas e Engrenagens das Ciencias Sociais. Rio de Janeiro: Relume Dumara. 106.

Fearnside, P. M., Nogueira, E. U., \& Yanai, A. M. (2018). Maintaining carbon stocks in extractive reserves in Brazilian Amazonia. Desenvolvimento e Meio Ambiente, 48, 446-476. https://doi.org/10.5380/dma.v48i0.58780

Garrett, R., Gardner, T., Morello, T., Marchand, S., Barlow, J., Blas, D., Ferreira, J., Lees A., \& Parry, L. (2017). Explaining the persistence of low income and environmentally degrading land uses in the brazilian Amazon. Ecology and Society, 22(3), 1-27. https://doi.org/10.5751/ES-09364-220327

Gomes, C., Vadjunec, J., \& Perz, S. (2012). Rubber tapper identities: political-economic dynamics, livelihood shifts, and environmental implications in a changing Amazon. Geoforum, 43(2), 260-271. https://doi.org/10.1016/j.geoforum.2011.09.005

Haddad, R. D., Haddad, M. D., Melo, C. M., Madi, R., \& Coelho, A. S. (2019). Analise social, economica e histórica das reservas extrativistas da Amazonia: lutas e trajetórias. Espacio Abierto, 28(2), 85-102.

Helliwell, J. F., \& Putnam, R. D. (2007). Education and social capital. Eastern Economic Journal,33(1), 1-19. https://doi.org/10.1057/eej.2007.1

Herrera, S., \& Torrent, J. (2015). Proyecto hidroaysen: capitalismo extractivista, regulación estatal y acción colectiva en la Patagonia. Revista Latinoamericana, 14(40), 439-467. https://doi.org/10.4067/S0718-65682015000100021

Hogg, O., Huvenne, V., Griffiths, H., Dorschel, B., \& Linse, K. (2016). Landscape mapping at Sub-Antarctic South Georgia provides a protocol for underpinning large-scale marine protected areas. Scientific Reports, 6, 1-15. https://doi.org/10.1038/srep33163

Homma, A. K. O. (2011). Biodiversidade e biopirataria na Amazonia: como reduzir os riscos? Passages de Paris, 6, 111-128.

Homma, A. K. O. (2015). Em favor de uma nova agricultura na Amazonia. Revista Terceira Margem Amazonia, 1(5), 19-34.

Homma, A. K. O. (2016). A Imigracao Japonesa na Amazonia: sua contribuicao ao desenvolvimento agricola. Brasilia: Embrapa (2nd ed.). 255.

Hope, J. (2016). Losing ground? Extractive-led development versus environmentalism in the isiboro Secure Indigenous Territory and National Park (TIPNIS), Bolivia. The Extractive Industries and Society, 3(4), 922-929. https://doi.org/10.1016/j.exis.2016.10.005

IBGE. Instituto Brasileiro de Geografia e Estatistica. (2010). Senso demografico. Retrieved June 1, 2021, from http://www.censo2010.gov.br/ sinopse/index.php?dados=P6\&uf $=00$

ICMBio. Instituto Chico Mendes de Conservacao da Biodiversidade. (2021). Unidades de Conservacao no Brasil. Retrieved June 10, 2021, from https://uc.socioambiental.org/pt-br/arp/628

Jaramillo-Giraldo, C., Soares-Filho, B., Ribeiro, S., \& Goncalves, R. (2017). Is it possible to make rubber extraction ecologically and economically viable in the Amazon? The southern Acre and Chico Mendes Reserve case study. Ecological Economics, 134, 186-197. https://doi.org/10.1016/j.ecolecon.2016.12.035

Klimas, C., Cropper Jr., W., Kainer, K., \& Wadt, L. (2012). Viability of combined timber and non-timber harvests for 
one species: a carapa guianensis case study. Ecological Modelling, 246, 147-156. https://doi.org/10.1016/j.ecolmodel.2012.07.022

Kröger, M. (2019). Deforestation, cattle capitalism and neodevelopmentalism in the Chico Mendes Extractive Reserve, Brazil. The Journal of Peasant Studies, 1-19. https://doi.org/10.1080/03066150.2019.1604510

Lagesse, J., \& Thondhlana, G. (2016). The effect of land-use on small mammal diversity inside and outside the great fish River Nature Reserve, Eastern Cape, South Africa. Journal of Arid Environments, 130, 76-83. https://doi.org/10.1016/j.jaridenv.2016.03.006

Lavoie, A., \& Brannstrom, C. (2019). Assembling a marine extractive reserve: the case of the Cassuruba RESEX in Brazil. Journal of Latin American Geography, 18(2), 120-151. https://doi.org/10.1353/lag.2019.0036

Lopes, E., Soares-Filho, B., Souza, F., Rajao, R., Merry, F., \& Carvalho Ribeiro, S. (2019). Mapping the socio-ecology of Non Timber Forest Products (NTFP) extraction in the Brazilian Amazon: the case of acai (Euterpe precatoria Mart) in Acre. Landscape and Urban Planning, 188, 110-117. https://doi.org/10.1016/j.landurbplan.2018.08.025

Lui, G., \& Coomes, D. (2016). Tropical nature reserves are losing their buffer zones, but leakage is not to blame. Environmental Research, 147, 580-589. https://doi.org/10.1016/j.envres.2015.11.008

Maciel, R., Reydon, B., Costa, J., \& Sales, G. (2010). Pagando pelos servicos ambientais: uma proposta para a Reserva Extrativista Chico Mendes. Acta Amazonica, 40(3), 489-498. https://doi.org/10.1590/S0044-59672010000300007

Mascarenhas, F. S., Brown, I. F., \& Silva, S. (2018). Desmatamento e incendios florestais transformando a realidade da Reserva Extrativista Chico Mendes. Desenvolvimento e Meio Ambiente, 48, $236-262$. https://doi.org/10.5380/dma.v48i0.58826

MMA. Ministerio do Meio Ambiente. (2014). Plano de Manejo da Reserva Extrativista Rio Ouro Preto. Retrieved June 11, 2021, from https://www.icmbio.gov.br/portal/images/stories/imgs-unidadescoservacao/Versao_completa_21_08_2014_com_mapas.pdf

Moraes, A., Alves, J., Kawakami, C., \& Leitao, A. (2015). Criacao de conselhos gestores de unidades de conservacao na amazonia: contribuicões metodológicas a partir da experiencia no interflúvio madeira-purus, amazonas. In: Pereira, H., \& Silva, M. (Orgs). Unidade de Conservacao do Amazonas no Interflúvio Purus-Madeira: instrumentos de gestao paticipativa. Manaus: EDUA, 111-131.

Moura, R., Minte-Vera, C., Curado, I., Francini-Filho, R., Rodrigues, H., Dutra, G., Alves, D., \& Souto, F. (2009). Challenges and prospects of fisheries co-management under a marine extractive reserve framework in Northeastern Brazil. Coastal Management, 37, 617-632. https://doi.org/10.1080/08920750903194165

Newton, P., Endo, W., \& Peres, C. (2011). Determinants of livelihood strategy variation in two extractive reserves in Amazonian flooded and unflooded forests. Environmental Conservation, 39(2), 97-110. https://doi.org/10.1017/S0376892911000580

Nogueira, E., Yanai, A., Vasconcelos, S., Graca, P., \& Fearnside, P. (2018). Carbon stocks and losses to deforestation in protected areas in Brazilian Amazonia. Regional Environmental Change, 18, 261-270. https://doi.org/10.1007/s10113-017-1198-1

Pelegrina-Lopeza, A., Ocana-Peinado, F., Henares-Civantos, I., Rosua-Campos, J., \& Serrano-Bernardo, F. (2017). Analyzing social perception as a key factor in the management of protected areas: the case of the Sierra Nevada Protected Area (S Spain). Journal of Environmental Planning and Management, 6(1), 1-19. https://doi.org/10.1080/09640568.2017.1291413

Peres, C. (2011). Conservation in sustainable-use tropical forest reserves. Conservation Biology, 25(26), 1124-1129. https://doi.org/10.1111/j.1523-1739.2011.01770.x

Ribeiro, S. C., Selaya, N. G., Perz, S. G., Brown, F., Schmidt, F. A., Silva, R. C., \& Lima, F. (2020). Aligning conservation and development goals with rural community priorities: capacity building for forest health monitoring in an extractive reserve in Brazil. Ecology and Society, 25(3), 1-13. https://doi.org/10.5751/ES-11665-250305

Santana, R. S., \& Pedroso, S. (2019). Evaluation of the advancing deforestation in the state Extractive Reserve of JaciParana - RO, between 1996 and 2016. Terra@Plural, 13(1), 93-105. https://doi.org/10.5212/TerraPlural.v.13i1.0006

Silva, J. B., Simonian, L., Costa, A. P., \& Batista, I. D. S. (2013). Sustentabilidade institucional em reservas extrativistas na Amazonia Brasileira. Papers do Naea, 316, 1-20.

Song, X., Huang, Y., Fu, J., Jiang, D., \& Tian, G. (2017). Spatial variability and ecological effects of anthropogenic activities in a nature reserve: a case study in the Baijitan National Nature Reserve, China. Sustainability, 9(2), 1-14. https://doi.org/10.3390/su9020239 
Teisserenc, M. J. (2016). Politizacao, ambientalizacao e desenvolvimento territorial em reservas extrativistas. Cadernos CRH, 29(77), 229-242. http://doi.org/10.1590/S0103-49792016000200003

Vitali, M., \& Uhlig, V. (2010). Unidades de Conservacao de Santa Catarina. Sustentabilidade em Debate, 1(1), 44-61. https://doi.org/10.18472/SustDeb.v1n1.2010.729

Volpato, G. L. (2013). Ciencia: da filosofia à publicacao (6th ed.). Sao Paulo: Cultura Academica. 377.

Volpato, G. L. (2015). O metodo lógico de redacao cientifica. Reciis, 9(1), 1-14. https://doi.org/10.29397/reciis.v9i1.932

Volpato, G. L. (2017). Metodo lógico para redacao cientifica (2nd ed.). Botucatu: Best Writing. 156.

Walter, M., Tomas, S., Munda, G., \& Larrea, C. (2016). A social multi-criteria evaluation approach to assess extractive and non-extractive scenarios in Ecuador: intag case study. Land Use Policy, 57, 444-458. https://doi.org/10.1016/j.landusepol.2016.05.030

Weisse, M., \& Naughton-Trevesweisse, L. (2016). Conservation beyond park boundaries: the impact of buffer zones on deforestation and mining concessions in the peruvian Amazon. Environmental Management, 58, $297-311$. https://doi.org/10.1007/s00267-016-0709-z

\section{Copyrights}

Copyright for this article is retained by the author(s), with first publication rights granted to the journal.

This is an open-access article distributed under the terms and conditions of the Creative Commons Attribution license which permits unrestricted use, distribution, and reproduction in any medium, provided the original work is properly cited. 